\title{
14
}

\section{Importation and Indigeneity: The Quartet in New Zealand Administrative Law}

\author{
DEAN R KNIGHT*
}

\section{INTRODUCTION}

W HAT INFLUENCE DID the famous Quartet of English cases - Ridge $v$ Baldwin, ${ }^{1}$ Padfield $v$ Minister of Agriculture, Fisheries and Food ${ }^{2}$ Conway $v$ Rimmer $^{3}$ and Anisminic $v$ Foreign Compensation Commission $^{4}$ - have on judicial review in New Zealand?

As an offspring of the English system of judicial review, it is no surprise that these cases were faithfully followed in the South Pacific, as New Zealand's supervisory jurisdiction echoed developments in the motherland. ${ }^{5}$ Each of the key cases found its way into the administrative law jurisprudence in New Zealand, with the English developments generally being mirrored locally. We can point to local landmark cases which echo the different turns, along with lines of authority that still carry the colour of the Quartet. Sometimes with embellishment, sometimes with a little erosion. And the cases that make up the Quartet continue to be cited today, sometimes in their own right and sometimes to fortify the analogical local precedents.

* Thanks, subject to the usual caveat, to Eddie Clark, Sir Ken Keith, Geoff McLay and the editors of this volume for comments and feedback. Thanks also to William Britton, Anna Prestidge and Pita Roycroft for research assistance.

${ }^{1}$ Ridge v Baldwin [1964] AC 40 (HL).

${ }^{2}$ Padfield $v$ Minister of Agriculture, Fisheries and Food [1968] AC 997 (HL).

${ }^{3}$ Conway v Rimmer [1968] AC 910 (HL).

${ }^{4}$ Anisminic v Foreign Compensation Commission [1969] 2 AC 147 (HL).

${ }^{5}$ For the purposes of simplicity, I use the terms 'England' and 'English' to capture the system of judicial review in England and Wales; see generally R Ireland, 'Law in Wales' in P Cane and J Conaghan (eds), The New Oxford Companion to Law (Oxford, OUP, 2008) 1231; and T Jones and J Williams 'Wales as a Jurisdiction' [2004] PL 78. 
But there is another side to this story. Parallel to the continuing importation of English developments, we can also detect a fledging fight for indigeneity on the part of the New Zealand courts. A creation story of sorts - the struggle of an offspring judiciary and an inherited common law to blossom in its own right. The last half century or so has seen the maturation and patriation of the local judiciary, as a matter of institutional form. For example, a permanent Court of Appeal was established in 1958 and subsequently the Supreme Court as final appellate court in 2004. But has that institutional development been matched by jurisprudential substance? In the mid-1980s, Lord Cooke said: 'The time has probably come to emphasise that New Zealand administrative law is significantly indigenous'. ${ }^{6}$ The Quartet provides a useful starting point to explore the question of indigeneity.

I track these parallel stories by first focusing on the importation point: the reception of the principle represented by the Quartet in New Zealand jurisprudence. I explain the local landmark cases in some detail, while also providing, as necessary, a brief sketch of broader context before and after. I then reflect on the question of indigeneity and whether the treatment of the Quartet provides any signals about a uniquely New Zealand jurisprudence. In the end, we see a fair bit of importation, along with some doses of indigeneity - at least in relation to the lines of jurisprudence flowing from the Quartet. The struggle between importation and indigeneity is an ongoing project for judicial review in New Zealand and is deserving of continued attention.

\section{THE QUARTET IN NEW ZEALAND}

\section{A. Ridge $v$ Baldwin}

Daganayasi is usually regarded as being the key New Zealand case on the generous approach adopted toward natural justice. ${ }^{7}$ This means it is often identified as the local counterpart to Ridge $v$ Baldwin, although Dagayanasi was about the content of natural justice rather than its applicability. But numerous cases, before and after Daganayasi, nodded to the generalisation of natural justice in Ridge $v$ Baldwin and its instrumental impact on the position in New Zealand.

Prior to Ridge $v$ Baldwin, the New Zealand courts applied the then traditional English approach when assessing whether natural justice applied, based on whether the decision-maker was obliged to act judicially. ${ }^{8}$ The first mention

\footnotetext{
${ }^{6}$ Budget Rent A Car Ltd v Auckland Regional Authority [1985] 2 NZLR 414 (CA) 418.

${ }^{7}$ Daganayasi $v$ Minister of Immigration [1980] 2 NZLR 130 (CA).

${ }^{8}$ See eg New Zealand Dairy Board v Okitu Co-operative Dairy Co Ltd [1953] NZLR 366; New Zealand United Licensed Victuallers Association of Employers v Price Tribunal [1957] NZLR 167 (CA); Buller Hospital Board v Attorney-General [1959] NZLR 1259 (CA), drawing on especially $R v$ Electricity Commissioners, ex parte London Electricity Joint Committee Co (1920) Ltd [1924] 1 KB 171 (CA), R v Legislative Committee of the Church Assembly [1928] $1 \mathrm{~KB} 411$ and
} 
of Ridge $v$ Baldwin was oddly in a private law case, AC Hatrick (NZ) Ltd, where the case provided assistance on the question of whether natural justice principles should be imported into arbitration provisions in a building contract. ${ }^{9}$ Ridge $v$ Baldwin was also warmly received and generously cited by the Court of Appeal in Jeffs, even though the case itself concerned a different dimension of natural justice (delegation). ${ }^{10}$ Ridge $v$ Baldwin was, curiously, not referred to by the Privy Council or the local lower courts in Furnell. ${ }^{11}$ The case was a significant one about whether a teacher was entitled to be heard in relation to a preliminary decision to suspend him pending investigation for misconduct (the Privy Council ruling the legislative scheme meant he did not). Yet, Furnell reflects the principle in Ridge $v$ Baldwin. Delivering the majority's decision, Lord Morris expressed the principle so tritely there was no need for any citation: 'Natural justice is but fairness writ large and juridically. It has been described as "fair play in action". Nor is it a leaven to be associated only with judicial or quasi-judicial occasions.' 12

Thus, it fell to the Court of Appeal in Lower Hutt City Council v Bank to directly herald the reception of Ridge $v$ Baldwin. ${ }^{13}$ When ruling a city council was obliged to afford natural justice to affected persons when considering whether to stop a street, McCarthy P acknowledged the death of the 'clearcut distinction' between administrative and judicial functions and the rise of a generalised approach to natural justice. In doing so, he singled out Lord Reid's speech in Ridge $v$ Baldwin as one of the 'directions from highest authority' that had led to these distinctions being 'blurred'. ${ }^{14}$ Numerous other cases followed suit. 15

As mentioned, the spirit of Ridge $v$ Baldwin is most vividly seen, though, in Dagayanasi, a case in 1980 addressing when the requirements of natural justice require disclosure of adverse material to an affected person. ${ }^{16}$ An overstayer

Nakkuda Aliv Jayaratne [1951] AC 66 (PC). See generally, K Keith, 'Ridge v Baldwin-twenty years on' (1983) 13 Victoria University of Wellington Law Review 239; DE Paterson, 'Lord Reid and the Writ of Certiorari' [1966] NZLJ 107; GDS Taylor, 'Natural Justice - the Modern Synthesis' (1975) 1 Monash University Law Review 258.

${ }^{9}$ AC Hatrick (NZ) Ltd $v$ Nelson Carlton Construction Co Ltd (In Liquidation) [1964] NZLR 72 (HC) 85 .

${ }^{10} \mathrm{Jeffs} v$ New Zealand Dairy Production and Marketing Board [1966] NZLR 73 (CA) (subsequently overturned by the Privy Council: Jeffs $v$ New Zealand Dairy Production Marketing Board [1967] 1 AC 551, [1967] NZLR 1057 (PC)).

${ }^{11}$ Furnell $v$ Whangarei High Schools Board [1973] AC 660, [1973] 2 NZLR 705 (PC); Whangarei High Schools Board v Furnell [1971] NZLR 782 (CA); Furnell v Whangarei High Schools Board SC Auckland, 22 October 1970.

${ }^{12}$ Furnell (PC) (n 11) 718.

${ }^{13}$ Lower Hutt City Council v Bank [1974] 1 NZLR 545 (CA).

14 ibid 593 (citations omitted).

${ }^{15}$ DG Allan Ltdv Blakely [1974] 2 NZLR 723 (CA); Otago Polytechnic Councilv Teachers Court of Appeal [1976] 2 NZLR 91 (SC); Ronaki Ltd $v$ Number One Town and Country Planning Appeal Board [1977] 2 NZLR 174 (CA); Chandra v Minister of Immigration [1978] 2 NZLR 559 (SC). For a blip along the way, Meadowvale Stud Farm Ltd $v$ Stratford County Council [1979] 1 NZLR 342 (SC).

${ }^{16}$ Daganayasi (n 7). 
sought ministerial intervention to stay her deportation due to her son's medical condition; the controlling legislation provided a ministerial discretion to do so if they were satisfied that, 'because of exceptional circumstances of a humanitarian nature, it would be unduly harsh or unjust to deport the offender from New Zealand'. But the minister refused, relying on a (undisclosed) doctor's assessment that the boy could be adequately treated abroad. When the case came to the Court of Appeal, Cooke J deftly took the opportunity to endorse the trajectory of natural justice following Ridge $v$ Baldwin: ${ }^{17}$

Perhaps it is as well to repeat some points that by 1980 have become fairly elementary. The requirements of natural justice vary with the power which is exercised and the circumstances. In their broadest sense they are not limited to occasions which might be labelled judicial or quasi-judicial. Their applicability and extent depend either on what is to be inferred or presumed in interpreting the particular Act (as is suggested by the speech of Lord Hailsham LC in Pearlberg $v$ Varty) or on judicial supplementation of the Act when this is necessary to achieve justice without frustrating the apparent purpose of the legislation (as Lord Reid put it in Wiseman v Borneman).

The principle in Ridge $v$ Baldwin was perhaps already so elementary that the case itself did not need to be explicitly cited in support, even though the case clearly underpinned the statement of principle!

Cooke J returned to Ridge $v$ Baldwin when discussing four specific cases he obtained guidance from. He commended Lord Reid's distinction between 'an exercise of power on a large scale and one relating solely to the treatment of an individual', noting that the former was 'more difficult for the Court to control'. ${ }^{18}$ The controlling provision, Cooke J said, 'makes it perfectly clear that the individual circumstances are the crucial consideration' and this was 'a pointer towards a procedure ensuring that the individual circumstances can be fairly assessed'. ${ }^{19}$ To this he added the Durayappah case and its identification of the types of matters that should be taken in account, beyond the language of the provision, when assessing whether the audi alteram partem principle applied. ${ }^{20}$ While Durayappah invited consideration of the nature of the property, office or status at stake, Cooke J did not think this dimension should be 'dominated by what is now commonly seen as a nineteenth-century concentration on the rights of property'. ${ }^{21}$ Instead, he pointed to the hope the mother might have of a favourable decision - or 'something akin to a legitimate expectation'.22 The mandated circumstances of intervention ('narrowly defined in the Act') and the sanctions ('lift[ing] the drastic sanction of deportation') also required

\footnotetext{
17 ibid 141. Both Richmond P and Richardson J endorsed Cooke J's analysis of natural justice but preferred to leave open the separate question addressed by Cooke J about whether mistake of fact should be recognised as a ground of review.

18 ibid 143 (citations omitted).

19 ibid 143.

${ }^{20}$ ibid, citing Durayappah v Fernando [1967] 2 AC 337 (PC).

21 ibid 144.

22 ibid.
} 
consideration. Cooke J also drew on Jeffs, which emphasised concern about decision-makers acting in ignorance of the evidence. ${ }^{23}$ The risk was the medical report 'was likely to have given a wrong impression of the evidence'. ${ }^{24}$ Also providing guidance was Ryan: a Privy Council case which itself made 'special reference' to Ridge $v$ Baldwin and spoke of the importance of providing a right to be heard when determining a question affecting the rights of individuals. ${ }^{25}$

These factors wove together to highlight the importance of fairness and natural justice being afforded to the mother, such that the medical report or an adequate summary be disclosed 'to allow her a reasonable opportunity of answering them'. ${ }^{26}$ And Cooke J concluded by noting that the requirements of fairness should not trouble the administration: fairness is 'not a rigorous or technical test' and 'should not cause any concern that administrative efficiency will be unduly shackled'. ${ }^{27}$ Thus, the Court concluded that the mother's application for humanitarian relief was 'not validly dealt with' by the minister. ${ }^{28}$ As she had been deported while her appeal was pending, the Court allowed her appeal and made a declaration accordingly.

Since then, Dagayanasi has come to represent the orthodoxy in New Zealand: a simplified and generous approach to natural justice and procedural fairness. ${ }^{29}$ And Ridge $v$ Baldwin, too, continues to be cited on numerous occasions. ${ }^{30}$ For example, the Supreme Court in Wyeth relied on both Dagayanasi and Ridge $v$ Baldwin when recounting the 'fairly elementary' position to natural justice in New Zealand, in a case turning on the nature of the natural justice entitlement. ${ }^{31}$ The key passage from Daganayasi (quoted above) which implicitly recognised the work of Ridge $v$ Baldwin was quoted and endorsed; so too was Ridge $v$ Baldwin approvingly mentioned. ${ }^{32}$

\footnotetext{
${ }^{23}$ ibid, citing Jeffs (n 10).

24 ibid.

25 ibid 144, citing Attorney-General v Ryan [1980] AC 718 (PC).

26 ibid 145.

27 ibid.

28 ibid 149.

${ }^{29}$ For example, see Fraser $v$ State Services Commission [1984] 1 NZLR 116 (CA) 121 which referred to Daganayasi, along with Ronaki Ltd $v$ Number One Town and Country Planning Appeal Board [1977] 2 NZLR 174, as a summary of New Zealand's principles and authorities on natural justice. Daganayasi continues to be cited in modern cases as such: eg Graeme Martin Contracting Ltd $v$ Disputes Tribunal [2018] NZCA 328; Obiaga v Visiting Justice at Auckland Prison [2018] NZHC 3095 [14]; Contact Energy Ltd v Moreau [2018] NZHC 2884.

${ }^{30} \mathrm{~W} v$ Health Practitioners Disciplinary Tribunal [2019] NZHC 420; Wilson $v$ R [2015] NZSC 189, [2016] 1 NZLR 705; Guy $v$ R [2014] NZSC 165, [2015] 1 NZLR 315; Wyeth (NZ) Ltd $v$ Ancare New Zealand Ltd [2010] NZSC 46, [2010] 3 NZLR 569; Combined Beneficiaries Union Inc v Auckland City COGS Committee [2008] NZCA 423, [2009] 2 NZLR 56; R v Smith [2003] 3 NZLR 617 (CA); B v Attorney-General [1999] 2 NZLR 296 (CA); Royal Australasian College of Surgeons $v$ Phipps [1999] 3 NZLR 1 (CA); Peters v Davison [1999] 2 NZLR 164 (CA); Tertiary Institutes Allied Staff Association Inc v Tahana [1998] 1 NZLR 41 (CA); Estate Homes Ltd v Waitakere City Council [2006] 2 NZLR 619 (CA).

${ }^{31}$ Wyeth [40], drawing on Cooke J's words in Daganayasi (n 7) 141.

${ }^{32}$ Wyeth (n 30) [42].
} 


\section{B. Padfield $v$ Minister of Agriculture, Fisheries and Food}

New Zealand's landmark cases of Ireland and Unison Networks are usually taken as the analogical expression of the purpose principle in Padfield. ${ }^{33}$ But, in truth, the purpose principle - the idea that discretion must be exercised for mandated purposes (namely, the policy and objects of the statute or other instrument conferring power), not ulterior or improper purposes - has been deeply ingrained into the common law method in administrative law, ${ }^{34}$ along with allied approaches to statutory interpretation..$^{35}$

As a common law ground of review, the improper purpose ground can be seen in a variety of cases. ${ }^{36}$ Even before Padfield, the courts recognised that decisionmakers could not exercise their powers for purposes other than the mandated purpose. ${ }^{37}$ Padfield received an early incidental mention from Wild CJ in Shand, in the course of rejecting an allegation that a minister had exercised his power to close a railway in a bona fide manner. ${ }^{38}$ Cooke $\mathrm{J}$ subsequently endorsed the principle, albeit in an obiter aside, in the Court of Appeal's decision in New Zealand Institute of Agricultural Science Inc v Ellesmere County. ${ }^{39}$ Numerous references to the principle followed. ${ }^{40}$ Poananga was a notable

\footnotetext{
${ }^{33}$ Attorney-General v Ireland [2002] 2 NZLR 220 (CA); Unison Networks Ltd v Commerce Commission [2007] NZSC 74, [2008] 1 NZLR 42.

${ }^{34} \mathrm{H}$ Wilberg, 'The Ireland Principle on Unauthorised but not Improper Purposes: An Exploration and Defence' [2016] 1 New Zealand Law Review 95; and M Smith, The New Zealand Judicial Review Handbook, 2nd edn (Wellington, Thomson Reuters, 2016). For its kindred principle, relevancy, see CREEDNZ Inc v Governor-General [1981] 1 NZLR 172 (CA).

35 The legislative direction on statutory interpretation requires the meaning of an enactment to 'be ascertained from its text and in the light of its purpose': Interpretation Act 1999, s 5(1) (emphasis added). For background, see Law Commission, 'Legislation and its Interpretation' (NZLC PP8, 1988) 20 citing Northland Milk Vendors Association Inc v Northern Milk Ltd [1988] 1 NZLR 530 (CA). The emphasis on text and purpose can be traced back to 1881: C Nijman, 'Ascertaining the Meaning of Legislation - A Question of Context' (2007) 38 Victoria University of Wellington Law Review 629, 630. See also J Burrows, 'Approaches to Statutory Interpretation' in Law Commission, Legislation and its Interpretation 130 citing Lord Diplock in Carter v Bradbeer [1975] 1 WLR 1204 (HL) 1206.

${ }^{36}$ In some cases, Associated Provincial Picture Houses Ltd $v$ Wednesbury Corporation [1948] 1 KB 223 was cited as the leading authority for the proposition, rather than Padfield; see eg Buller Hospital Board (n 8) 1271; Opua Coastal Preservation Inc v Far North District Council [2018] NZCA 262, [2018] 3 NZLR 538 (CA) [107]; Environmental Defence Society Inc v South Pacific Aluminium Ltd (No 2) [1981] 1 NZLR 153 (CA) 164.

${ }^{37}$ See eg Quinlan v Mayor, etc of Wellington [1929] NZLR 491 (SC); McKenna v Palmerston North City Corporation [1952] NZLR 767 (SC).

${ }^{38}$ Shand $v$ Minister of Railways [1970] NZLR 615 (SC) (although not mentioned in subsequent appeal: Shand $v$ Minister of Railways [1970] NZLR 615 (CA)).

${ }^{39}$ New Zealand Institute of Agricultural Science Inc v Ellesmere County [1976] 1 NZLR 630 (CA) 637.

${ }^{40}$ See eg Rowling $v$ Takaro Properties Ltd [1975] 2 NZLR 62 (CA); Takaro Properties Ltd $v$ Rowling [1987] 2 NZLR 700, [1988] AC 473 (PC); Murdoch v New Zealand Milk Board [1982] 2 NZLR 108 (HC); Transport Ministry $v$ Alexander [1978] 1 NZLR 306 (CA); Fiordland Venison Ltd $v$ Minister of Agriculture and Fisheries [1978] 2 NZLR 341 (CA); Dannevirke Borough Council v Governor-General [1981] 1 NZLR 129 (HC); Ashby v Minister of Immigration [1981] 1 NZLR 222 (CA) 230 (per Richardson J); Brightwell v Accident Compensation Corporation [1985]
} 
instance of the force of the principle, where the decision to transfer a government employee to another department - for unauthorised punitive purposes, rather than for mandated administrative reasons - was quashed; while Padfield itself was not cited by any of the Court of Appeal judges, it seems clear that Poananga followed that tradition. ${ }^{41}$

It is Ireland which came to be associated with Padfield in the modern era, perhaps oddly. ${ }^{42}$ The case concerned the use of a historic purpose reserve North Head, a former site of Māori occupation and later coastal defence site - by a department to house its regional operations. The controlling legislation permitted the administering department to do 'such things as may be considered necessary or desirable for the proper and beneficial management, administration, and control of the reserve'. At first instance, the High Court ruled that such use was improper and unlawful. While there was some benefit arising from occupation of the buildings for the local reserve itself, there was also material benefit for the wider region; in other words, an ulterior purpose. On appeal, the Court of Appeal took a different approach to addressing questions of lawfulness when there was both a legitimate and ulterior purpose present. Drawing on, amongst other cases, Padfield, Keith J said 'purposes not within the statute are not necessarily "invalid" or "improper"; the additional pursuit of such other purposes may not thwart or frustrate the policy of the Act in question' ${ }^{43}$ Mere presence of an ulterior purpose was not enough. Thus, as the statutory purpose was satisfied and the additional purpose did not prejudice that purpose, the department's actions were not unlawful.

The Supreme Court's decision in Unison Networks also strongly endorsed Padfield's purpose principle. ${ }^{44}$ The point arose in discussion of the Commerce Commission's regulation of the prices charged by electricity line companies; a price threshold was set which, if breached by any line company, would trigger further investigation and, perhaps, the imposition of price controls. Unison was aggrieved by the price threshold, which it thought amounted to an effective price freeze for over two and a half years. It argued that such an approach was not justified under the legislation, which had as its mandated purpose the promotion of the efficient operation of electricity distribution markets for the long-term benefit of consumers, through targeted control of line companies extracting excessive profits. The Supreme Court did not accept that the imposition of a

1 NZLR 132 (CA); New Zealand Maori Council v Attorney-General [1987] 1 NZLR 641 (CA) 678 (per Richardson J); R v Salmond [1992] 3 NZLR 8 (CA); and Mackenzie District Council v Electricity Corporation of New Zealand [1992] 3 NZLR 41 (CA).

${ }^{41}$ Poananga $v$ State Services Commission [1985] 2 NZLR 385 (CA); see eg Somers J's reference to the section of W Wade, Administrative Law, 5th edn (Oxford, Clarendon Press, 1982) 369 which addresses relevancy and purpose, including discussion of Padfield.

${ }^{42}$ Ireland (n 33). See also PF Sugrue Ltd v Attorney-General [2005] UKPC 44, [2006] 3 NZLR 464 [20] and [23]-[24].

${ }^{43}$ Ireland (n 33) [42]. Keith J noted Cooke J in Poananga (n 41) used similar language too.

${ }^{44}$ Unison Networks Ltd $v$ Commerce Commission [2007] NZSC 74, [2008] 1 NZLR 42. 
blanket price threshold trigger was outside the mandated purpose; it was sufficient that the price threshold was 'relevant to that purpose in the sense that [the threshold] will contribute to the administration of the targeted control regime'. ${ }^{45}$ In reaching this conclusion, McGrath J directly incorporated the language from Padfield into the key statement of principle: ${ }^{46}$

A statutory power is subject to limits even if it is conferred in unqualified terms. Parliament must have intended that a broadly framed discretion should always be exercised to promote the policy and objects of the Act. These are ascertained from reading the Act as a whole. The exercise of the power will be invalid if the decision maker 'so uses his discretion as to thwart or run counter to the policy and objects of the Act'.

He also went on to endorse the treatment of multiple purposes in the earlier Ireland case; pursuit of a collateral improper purpose only invalidates the decision if it compromises the legitimate purpose. ${ }^{47}$

Since Unison Networks, the purpose principle has continued to be applied in those terms, sometimes with the citation of Unison Networks, sometimes with the citation of Padfield, and sometimes with both. ${ }^{48}$

The commitment to Padfield's purpose principle thus seems, at first blush, quite strong in New Zealand. Yet, there is a sense the local sequels have somewhat eroded the force of the principle, despite their approval of Padfield itself. First, there is some concern that the approach to multiple purposes adopted in Ireland - namely, an action is unlawful only if the ulterior purpose undermines or thwarts the lawful purpose - gives too much potential for unlawful considerations to creep into the motivations of decision-makers. ${ }^{49}$ Secondly, the Supreme Court's application of the purpose principle in Unison Networks was quite deferential. ${ }^{50}$ The combination of a broadly expressed power and a public body with expertise on the subject matter meant 'wide policy considerations' may animate the decision; intervention was unlikely if the body, amongst other

${ }^{45}$ ibid [69].

${ }^{46}$ ibid [53].

${ }^{47}$ ibid [53].

${ }^{48}$ New Health $v$ New Zealand Inc v South Taranaki District Council [2018] NZSC 59 [317], [2018] 1 NZLR 948 (per Elias CJ); Brook Valley Community Group Inc v Brook Waimarama Sanctuary Trust [2018] NZCA 573; Attorney-General v Haronga [2016] NZCA 626, [2017] 2 NZLR 394; Royal Forest and Bird Protection Society of New Zealand Inc v Minister of Conservation [2016] NZCA 411, [2016] 3 NZLR 828; Criminal Bar Association of New Zealand Inc v Attorney-General [2013] NZCA 176, [2013] NZAR 1409; Back Country Helicopters Ltd v Minister of Conservation [2013] NZHC 982, [2013] NZAR 1474; Exide Technologies Ltd v Attorney-General [2011] NZCA 651; and Chief Executive of Department of Labourv Yadegary [2008] NZCA 295, [2009] 2 NZLR 495.

${ }^{49}$ P Joseph ‘Constitutional Law' [2012] New Zealand Law Review 515, 533-37. Compare Wilberg, 'The Ireland Principle' [2016]. In Criminal Bar Association of New Zealand Inc v Attorney-General, the Court of Appeal indicated that any revisiting of the approach adopted in Ireland was for the Supreme Court; while it may have been 'pro forma', the Supreme Court affirmed the Ireland case generally: Criminal Bar Association (n 43) [55].

${ }^{50} \mathrm{H}$ Wilberg, 'Administrative Law' [2010] New Zealand Law Review 177, 189. 
things, 'exercised the power in a way which cannot rationally be regarded as coming within the statutory purpose'. ${ }^{51}$ This implicitly suggests that the circumstances of some decisions may mean the judicial parsing of proper and improper is done with a light touch.

\section{Conway v Rimmer}

Conway $v$ Rimmer made less impression because New Zealand had earlier chosen not to adopt the conclusive approach to Crown privilege that Conway $v$ Rimmer sought to cure. Since 1936, the New Zealand courts had retained the right to examine documents to assess whether the public interest would be injuriously affected by production, ${ }^{52}$ based on the Privy Council's decision in 1932 in Robinson $v$ State of South Australia. ${ }^{53}$ It was after the adoption of the discretionary approach in Robinson that the House of Lords, in 1942, took a different, more conclusive approach in Cammell Laird. ${ }^{54}$

The conflicting approaches were not considered in New Zealand until the Court of Appeal's 1962 decision in Corbett. ${ }^{55}$ The Court of Appeal approached the conflict as a constitutional question about stare decisis, rather than a normative choice about the most appropriate principle. ${ }^{56}$ That is, should the New Zealand courts follow a House of Lords decision that was inconsistent with an earlier Privy Council decision? By majority, the Court of Appeal ruled there was no justification for adopting the House of Lords decision in Cammell Laird over the controlling Privy Council precedent in Robinson. ${ }^{57}$ Thus, the Court of Appeal affirmed the discretionary approach to Crown privilege: ${ }^{58}$

I am of opinion that we should re-affirm that Courts in New Zealand still possess the power to overrule a ministerial objection to the production of documents in respect of which privilege is claimed if they think it right to do so, but it should nevertheless be borne in mind that it is a power to be held in reserve and not to be lightly exercised.

Therefore, it took the House of Lords decision in Conway $v$ Rimmer in 1968 to bring harmony between English and New Zealand jurisprudence, but by reframing English law to coincide with New Zealand law. New Zealand's Corbett case was not, however, mentioned in the House of Lords decision.

\footnotetext{
${ }^{51}$ Unison Networks (n 44) [55].

${ }^{52}$ Gisborne Fire Board v Lunken [1936] NZLR 894 (CA).

${ }^{53}$ Robinson $v$ State of South Australia [1931] AC 70 (PC).

${ }^{54}$ Duncan $v$ Cammell Laird and Co Ltd [1942] AC 624 (HL).

${ }^{55}$ Corbett $v$ Social Security Commission [1962] NZLR 878 (CA).

${ }^{56}$ The Court of Appeal did record some of the criticism of the approach in Cammell Laird, but this did not directly affect the decision.

${ }^{57}$ Corbett $v$ Social Security Commission [1962] NZLR 878 (CA) (per North and Cleary JJ, Gresson P dissenting).

${ }^{58}$ ibid 911 (per North J). However, in the particular circumstances, the case for such a production order failed.
} 
Following the House of Lords decision in Conway $v$ Rimmer, the New Zealand Court of Appeal in Konia reaffirmed its commitment to a discretionary approach to Crown privilege, this time nodding to the English developments. ${ }^{59}$ McCarthy P explained that Corbett and Conway $v$ Rimmer were 'very much in parallel'. ${ }^{60}$ And, in resolving questions about the production of police [papers] subject to a claim of Crown privilege, the judges drew heavily on Conway $v$ Rimmer (as well as the Lewes Justices case). ${ }^{61}$ After inspection, the Court ordered the production of most of the documents on the basis that the public interest in the proper administration of justice outweighed the basis of the claims for Crown privilege.

Despite Conway $v$ Rimmer not being directly instrumental in kicking off the discretionary approach to Crown privilege in New Zealand, it continued to be cited as the 'leading case' in support of this approach. In Elston, Richardson J referred to Konia and the convergence of New Zealand and English approaches, but then went on to cite heavily from Conway $v$ Rimmer (and Lewes Justices). ${ }^{62}$ Ultimately he rejected most claims for the production of Cabinet papers and similar high-level documents. ${ }^{63}$ Ringing endorsement of Conway $v$ Rimmer (and Lewes Justices too) was also evident in the Court of Appeal's reasoning, delivered by Richardson J, in Tipene v Apperley. ${ }^{64}$ Subsequently, in Environmental Defence Society (No 2), the Court of Appeal distanced itself from the dicta in Conway $v$ Rimmer on the application of Crown privilege to Cabinet papers. ${ }^{65}$ Rejecting any suggestion of a firm rule about the non-production of Cabinet papers, ${ }^{66}$ the Court of Appeal ruled that, while deference would be shown to a ministerial certificate, the discretionary approach to Crown privilege was equally applicable to Cabinet papers. ${ }^{67}$ Thus, the Court inspected the Cabinet papers to determine whether they should be disclosed, but subsequently ruled they did not. ${ }^{68}$

${ }^{59}$ Konia v Morley; Cullen v Attorney-General [1976] 1 NZLR 455 (CA).

${ }^{60}$ ibid 460.

${ }^{61} R v$ Lewes Justices, ex parte Secretary of State for Home Department [1972] 1 QB 232.

${ }^{62}$ Elston v State Services Commission [1979] 1 NZLR 193 (SC) 197.

${ }^{6} 3$ ibid 201-02.

${ }^{64}$ Tipene $v$ Apperley [1978] 1 NZLR 761 (CA). The recent decision in D $v$ National Society for the Prevention of Cruelty to Children [1978] AC 171 (HL) was also referred to.

${ }^{65}$ Environmental Defence Society (No 2) (n 36).

${ }^{6}$ Both Richardson and McMullin JJ pointed to Conway v Rimmer as the 'leading English case' on the point, until the House of Lords and High Court of Australia signalled a different approach in Burmah Oil Co Ltd v Bank of England [1980] AC 1090 (HL) and Sankey v Whitlam (1978) 142 CLR 1 respectively.

${ }^{67}$ Environmental Defence Society (No 2) (n 36) 162. Cooke J, perhaps oddly, did not directly analyse the authorities, suggesting there would be no value embarking on 'a written analysis of the various shades of opinion and modes of expression in the speeches in the House of Lords and the judgments in the High Court of Australia'.

68 ibid 169. 
Subsequent cases also illustrate the discretionary approach and the influence of Conway $v$ Rimmer. ${ }^{69}$ The discretionary approach was applied in a number of cases in which disclosure was required, including, for example, Fletcher Timber, ${ }^{70}$ Brightwell ${ }^{71}$ and Birss. ${ }^{72}$ Conway $v$ Rimmer was directly cited and relied on in two of those three cases. Notably, too, the Court of Appeal in Brightwell fortified the discretionary approach with reference to the transparency principles evident in the Official Information Act 1981. Standing apart from the others is Choudry, where a minister's certificate about national security risks was ultimately sufficient to resist disclosure. ${ }^{73}$ Again, Conway $v$ Rimmer was extensively cited, even though the application of the principle weighed against disclosure. The Court expressed concern that the minister's reasons were 'of a character which judicial experience is not competent to weigh' and the judicial process was not able 'responsibly, to go behind a ministerial certificate that to disclose more would itself jeopardise national security' ${ }^{74}$

It also seems reliance on the Crown privilege waned in recent decades, as the spirit of transparency became stronger. ${ }^{75}$ And, following a major reform of the law of evidence, the discretionary approach to Crown privilege was codified in section 70 of the Evidence Act $2006 .^{76}$

\section{Anisminic v Foreign Compensation Commission}

Bulk Gas stands as New Zealand's Anisminic, where the protective cloak of non-jurisdictional errors is cast away in favour of more generalised review for

\footnotetext{
${ }^{69}$ See also $R v$ Strawbridge (Raymond) [2003] 1 NZLR 683 (CA).

${ }^{70}$ Fletcher Timber Ltd v Attorney-General [1984] 1 NZLR 290 (CA) (applicant did not have any onus to show documents likely to help their case; sufficient that documents were relevant).

${ }^{71}$ Brightwell v Accident Compensation Corporation [1985] 1 NZLR 132 (CA) (documents of independent body not immune merely because might be used by minister to formulate government policy).

72 Attorney-General v Birss [1991] 1 NZLR 669 (CA) 671 (fair trial needs outweighed confidentially concerns in relation to disclosure of transcript of evidence given to a commission of inquiry).

${ }^{73}$ Choudry v Attorney-General [1999] 2 NZLR 582 (CA) and Choudry v Attorney-General [1999] 3 NZLR 399 (CA) (court initially ruled the certificate was inadequate but allowed the Crown to provide another certificate with more specificity).

${ }^{74}$ Choudry v Attorney-General [1999] 3 NZLR 399 [31].

${ }^{75} \mathrm{M}$ Downs (ed), Cross on Evidence (online looseleaf edn, LexisNexis) at [EVA70.3]: 'In recent years the Crown has hardly ever claimed public interest immunity in litigation in New Zealand.'

${ }^{76}$ Under the Evidence Act 2006, s 70, a judge may direct that a communication or information relating to 'matters of State' not be disclosed if 'the public interest in the communication or information being disclosed in the proceeding is outweighed by the public interest in withholding the communication or information'. See Law Commission, 'Evidence Law: Privilege' (NZLC PP23, 1994) 148 and, for a recent example, Dotcom v Attorney-General [2019] NZCA 412, [2019] 3 NZLR 387. Also see, however, Crown Proceedings Act 1950, s 27 (3) (rules must provide Crown can refuse to confirm existence of certain documents if would prejudice natural security or the prevention, investigation, or detection of offences).
} 
error of law, effectively neutralising the effect of privative clauses. ${ }^{77}$ But the realisation of these developments took some time, ${ }^{78}$ as the jurisdictionalnon-jurisdictional dichotomy was deeply embedded in administrative law jurisprudence as a key mediating device regulating the degree of judicial deference. $^{79}$

It is no surprise that the first New Zealand judge to seize on Anisminic's approach to matters jurisdictional was Robin Cooke; his $\mathrm{PhD}$ thesis at Cambridge in the 1950 s addressed that very topic. ${ }^{80}$ For example, in the first instance decision in Car Haulaways - one of his early cases as a judge Cooke J nodded to the significance of the 'landmark' Anisminic case. ${ }^{81}$ Facing a privative clause purporting to exclude review 'except on the ground of lack of jurisdiction', ${ }^{82}$ Cooke J said the majority opinions in Anisminic 'should be accepted as authoritative in New Zealand'. ${ }^{83}$ Thus, although it was not strictly necessary for him to decide the point, he described the effect of the privative clause in the following terms: ${ }^{84}$

If an Act plainly empowers an authority ... to decide a question of law conclusively ... or if in exercising its true jurisdiction the tribunal decides a purely incidental question of law ... a clause [like section 164] makes the decision immune from challenge, even though an error of law may be apparent on the record ... Unless the errors of law ... go to jurisdiction, they are not redressible; although strictly speaking it is unnecessary for me to decide the point. A fortiori, findings of fact on the very question which the tribunal is set up to decide, and conclusions based on an evaluation of the evidence bearing on such questions, would be immune.

While the decision-maker had acted 'within the ambit of its statutory jurisdiction' in relation to most matters which had been subject to criticism, Cooke J identified three criticisms of the decision-making which went to jurisdiction and quashed the decision on the basis of those errors. On appeal, the Court of Appeal took a different view from Cooke J on whether those criticisms amounted to errors and overturned the first instance decision to intervene. ${ }^{85}$

\footnotetext{
${ }^{77}$ Bulk Gas Users Group v Attorney-General [1983] NZLR 129 (CA) [Bulk Gas (CA)].

${ }^{78}$ See also M Taggart, 'The Contribution of Lord Cooke to Scope of Review Doctrine in Administrative Law: A Comparative Common Law Perspective' in P Rishworth (ed), The Struggle for Simplicity in Law: Essays for Lord Cooke of Thorndon (Wellington, Butterworths, 1997) 189, where Robin Cooke's contribution on this point is traced in more detail.

${ }^{79}$ See eg Waterside Workers' Federation Industrial Association of Workers $v$ Frazer [1924] NZLR 689 (SC). See generally J Pemberton, 'The Judicial Approach to Privative Provisions in New Zealand' [2015] New Zealand Law Review 617, 619; and DR Knight, Vigilance and Restraint in the Common Law of Judicial Review (Cambridge, CUP, 2018) 48-50.

${ }^{80} \mathrm{R}$ Cooke, Jurisdiction: An Essay in Constitutional, Administrative and Procedural Law (PhD, University of Cambridge, 1954). See also Taggart, 'Lord Cooke' (1997) 190.

${ }^{81}$ Car Haulaways (NZ) Ltd v Attorney-General SC Auckland A8/73 (8 August 1973) 36.

${ }^{82}$ Transport Act 1962, s 164.

${ }^{83}$ Car Haulaways (n 81) 36.

${ }^{84}$ Car Haulaways (n 81) 36-37, as quoted in Attorney-General v Car Haulaways (NZ) Ltd [1974] 2 NZLR 331 (CA) 333.

${ }^{85}$ Car Haulaways (n 81).
} 
However, much of Cooke J's imprimatur of Anisminic was recorded without dissent from counsel or the Court of Appeal. ${ }^{86}$

Shortly thereafter, the Court of Appeal in the Engineering Union case recognised that Anisminic suggested a 'widening field of review' but the Court was also mixed about its implications in New Zealand and within the particular legislative framework in which the case arose. ${ }^{87}$ On the one hand, both McCarthy P and Richmond J signalled some tentative scepticism towards the Anisminic approach to privative clauses and jurisdictional error. ${ }^{88}$ On the other hand, Cooke J was quick to show his support for Anisminic's trajectory: ${ }^{89}$

First, my present opinion is that if Anisminic widened the field of jurisdictional review or jurisdictional error, it did so in the sense of preferring one of two longcompeting lines of reasoning and authority to the other. Secondly, I think the courts of general jurisdiction should be slow to hold that when establishing a court or tribunal of limited jurisdiction Parliament meant it to have authority to determine conclusively for the purposes of any given case the meaning of provisions in the Act by which it is constituted and under which it operates. Questions of fact or discretion are in a different category.

Strictly speaking, the remarks made about Anisminic were only obiter because the Court ruled the Court of Arbitration had not fallen into error in the case under review and were also expressed as tentative thoughts because the point was not subject to direct argument.

Thus, we had to wait 10 years to see the Anisminic tradition take hold in New Zealand in the 1983 case, Bulk Gas..$^{90}$ A dispute arose about the meaning of 'direct interest' in a code setting out consultation rights in relation to the imposition of price controls. The Secretary of Energy was charged with approving applications to increase the price of natural gas but was required to first consult with any persons who had a 'direct interest in the matter'. ${ }^{91}$ The Natural Gas Corporation applied to increase the price of gas it supplied to wholesalers. Bulk Gas Group, a collection of customers, sought to make submissions on that application. But Bulk Gas Group did not purchase gas directly from Natural Gas Corporation; they purchased gas from the Auckland Gas Company, the sole wholesaler within the region, who purchased the gas from Natural Gas Corporation. As they were not a direct customer of the Natural Gas Corporation, the best they could argue was that the price increase would inevitably be passed

\footnotetext{
${ }^{86}$ ibid 333. Sian Elias, later Chief Justice, appeared as junior counsel in her first appearance, arguing the legal point; S Elias, 'Righting Administrative Law' in D Dyzenhaus, M Hunt and G Huscroft (eds), A Simple Common Lawyer: Essays in Honour of Michael Taggart (Oxford, Hart Publishing, 2009) 58.

${ }^{87}$ New Zealand Engineering, Coachbuilding, Aircraft, Motor and Related Trades Industrial Union of Works $v$ Court of Arbitration [1976] 2 NZLR 283 (CA).

88 ibid 285 and 295.

89 ibid 301.

${ }^{90}$ Bulk Gas (CA) (n 77).

${ }^{91}$ Natural Gas (Price Restraint) Regulations 1981, reg 10 and Commerce Act 1975, ss 92 and 97.
} 
on to them by Auckland Gas Company. Ultimately, the Secretary ruled that the Bulk Gas Group did not have a direct interest in Natural Gas Corporation's application (but accepted they would have a direct interest in any application by Auckland Gas Company). Bulk Gas Group sought to judicially review the decision of the Secretary refusing its request to make submissions. But a privative clause potentially provided a hurdle to such a challenge; the clause said that a decision of the Secretary could not be 'challenged, reviewed, quashed or called in question' in court, except 'on the ground of lack of jurisdiction'. ${ }^{92}$

The High Court ruled that the Secretary's decision could not be impugned, because no jurisdictional error had been made. ${ }^{93}$ The question of whether Bulk Gas Group had a direct interest - a question on which there 'may well be room for judgment' - was a matter within the Secretary's jurisdiction to decide, 'even to decide it wrongly'; the language and scheme of the Act was such that Parliament had intended to leave that judgement to the Secretary. ${ }^{94}$ 'Judicial minds on this topic in England at least,' Davison CJ said, 'do not yet appear to be unanimous. ${ }^{95}$ Thus, he felt bound to apply the traditional jurisdictional approach. ${ }^{96}$

Bulk Gas Group appealed to the Court of Appeal, where the appeal was unanimously rejected. The Court of Appeal accepted the Secretary's approach to the question of 'direct interest'. Cooke J, with whom Somers J agreed, issued the lead judgment. ${ }^{97}$ Anisminic is boldly embraced and privative clauses effectively nullified, perhaps in even more simplified and constitutional terms that the landmark English case. ${ }^{98}$

The concept of jurisdiction is jettisoned (despite its operative role in the statutory privative clause): 'a rather elusive thing' and 'a vague and probably undefinable concept'. ${ }^{99}$ Instead, the focus turns to the question of whether the decision-maker has been empowered to decide conclusively. A privative clause does not apply 'if the decision results from an error on a question of law which the authority is not empowered to decide conclusively, even though in carrying

\footnotetext{
${ }^{92}$ Commerce Act 1975, s 96. The privative clause reflected in statutory form the common law position pre-Bulk Gas (CA): Taggart (n 78) 193.

${ }^{93}$ Bulk Gas Users Group v Attorney-General [1982] 2 NZLR 306 (HC) 314.

${ }_{94}$ Bulk Gas (HC) 312 and 314.

95 ibid 311.

${ }^{96} \mathrm{ibid}$; that is, Davison CJ wasn't prepared to follow the collapse of the distinction between jurisdictional and non-jurisdictional errors by Lord Denning and Lord Diplock in Pearlman v Keepers and Governors of Harrow School [1979] QB 56, [1978] 3 WLR 736 (CA) and Re Racal Communications Ltd [1981] AC 374 (HL) respectively.

${ }^{97}$ Bulk Gas (CA) (n 77). As Taggart notes, it is 'a difficult judgment to grasp', especially 'because of the intricacy of the reasoning': Taggart (n 78) 194.

${ }^{98}$ This nullification is effected, even though it is acknowledged that such clauses may be legally effective: Bulk Gas (CA) (n 77) 133: 'It is generally accepted in New Zealand that an Act may empower an authority to decide a question of law conclusively and that a privative clause of this kind will then protect the authority's decision even though an error of law (in the opinion of the Court) may be apparent on the record: Attorney-General $v$ Car Haulaways (NZ) Ltd.'

${ }^{99}$ Bulk Gas (CA) (n 77) 135. See also R Cooke, 'The Struggle for Simplicity in Administrative Law' in M Taggart (ed), Judicial Review of Administrative Action in the 1980s (Auckland, OUP, 1986).
} 
out its functions it will have to form a working opinion on the question' ${ }^{100}$ Anisminic is recorded as the 'modern leading case' on this point. ${ }^{101}$ Thus, Cooke $\mathrm{J}$ deftly reshapes the question into a more constitutional analysis, building on Lord Diplock's words in Racal Communications. ${ }^{102}$ 'The Courts of general jurisdiction will be slow to conclude,' Cooke J records, 'that power to decide a question of law conclusively has been conferred on a statutory authority or tribunal. ${ }^{103}$ Matters of legal interpretation are 'for courts of law to resolve in fulfilment of their constitutional role as interpreters of the written law and expounders of the common law and rules of equity'. ${ }^{104}$ The corollary of this proposition is that if empowering legislation laid down 'a definite test', a decision will be invalid if the decision-maker has not applied that test. ${ }^{105}$

Thus, the privative clause did not provide any impediment to the Court forming its own view on the meaning of 'direct interest' in the price-setting legislation - albeit the Court agreed with the Secretary's conclusion. ${ }^{106}$ The question was 'a pure question of statutory interpretation' (viz a 'definite test') and there was 'no good reason' why the Secretary should be treated as having the power to determine the question conclusively (in modern terms, an absence of relative expertise on the part of the decision-maker). ${ }^{107}$ Reaching the conclusion that the decision-maker was 'not exercising [their] true powers' in this matter was simply another way of saying that the privative clause did apply, 'because there [was] a lack of jurisdiction in the sense recognised in Anisminic'. ${ }^{108}$

Bulk Gas therefore built on Anisminic to mandate the courts' predominant role on questions of law - but through simplified constitutional reasoning rather than contorted linguistic gymnastics. The powerful role of the courts on matters of law is now vested deeply within the administrative and constitutional system in New Zealand. Any hint that a question raises a matter of law mandates close attention from the judiciary; deference on such matters has been strongly frowned on. 109

The Bulk Gas tradition has since had mixed success in the modern era. First, as it relates to review for error of law, the Court of Appeal in Peters $v$ Davison

\footnotetext{
${ }^{100}$ Bulk Gas (CA) (n 77) 133.

101 ibid 133. The Privy Council's decision in South East Asia Fire Bricks Sdn Bhdv Non-Metallic Mineral Products Manufacturing Employees Union [1981] AC 363 (PC) is also cited.

${ }^{102}$ Racal Communications (n 96).

${ }^{103}$ Bulk Gas (CA) (n 77) 133.

${ }^{104}$ Racal Communications (n 96) [14] (per Lord Diplock), adopted by Cooke J in Bulk Gas (CA) (n 77) 133.

${ }^{105}$ Bulk Gas (CA) (n 77) 133. Taggart (n 78) rightly ponders whether this caveat left the door open for deference on some questions of law to develop.

${ }^{106}$ Bulk Gas (CA) (n 77) 133.

107 ibid 135 and 136.

108 ibid 135.

${ }^{109}$ See Professor Taggart's critique of this approach: Taggart (n 78) and, for a recent update, see Wilberg, 'Administrative Law' [2010] 191.
} 
definitively confirmed the breadth of illegality as a ground of review and reiterated its commitment to Anisminic's direction of travel: ${ }^{110}$

Error of law is a ground of review in and of itself; it is not necessary to show that the error was one that caused the tribunal or Court to go beyond its jurisdiction. The effect of the House of Lords' decision in Anisminic Ltd v Foreign Compensation Commission as interpreted in O'Reilly $v$ Mackman, and in $R v$ Lord President of the Privy Council, ex parte Page, is in general to render redundant any distinction between jurisdictional and non-jurisdictional error of law.

The availability of error of law as a ground for review of the exercise of public power is also now well established in New Zealand as appears from the decisions of this Court in Bulk Gas Users Group v Attorney-General and Hawkins v Minister of Justice.

Peters $v$ Davison is now routinely cited in New Zealand on the nature and scope of the illegality ground. ${ }^{111}$

Secondly, as it relates to the effectiveness of privative clauses, the position in the modern era is more mixed, perhaps even inconsistent. ${ }^{112}$ On the one hand, received wisdom continues to be that courts generally interpret such clauses narrowly. ${ }^{113}$ As one judge observed, such a proposition 'hardly seemed to need authority'. ${ }^{114}$ On the other hand, the courts exhibit a degree of willingness to respect privative clauses and exclude review, at least in cases where the privative clauses protect other statutory dispute processes that adequately provide for judicial supervision of errors. In other words, the courts should also be mindful of 'Parliament's intention to prevent duplicative proceedings'. ${ }^{115}$

The narrow interpretation can be seen in a number of cases. For example, in Zaoui (No 2), the Court of Appeal rejected the Crown's argument that a privative clause (drafted in similar form to the one in Bulk Gas) protected errors made by the Inspector-General of Intelligence and Security when reviewing a security certificate issued in respect of a refugee. ${ }^{116}$ Material errors of law relating to the relevance of human rights instruments and need to provide a summary of allegations were not protected by the clause, especially when the privative clause

\footnotetext{
${ }^{110}$ Peters $v$ Davison [1999] 2 NZLR 164 (CA) 180 (citations omitted). See PA Joseph, 'The Demise of Ultra Vires' [2001] PL 354.

${ }^{111}$ See eg Ye v Minister of Immigration [2008] NZCA 291, [2009] 2 NZLR 596 (CA) [403] and Vector Ltd v Utilities Disputes Commissioner [2018] NZHC 3096 [7].

${ }^{112}$ Pemberton, 'Privative Provisions in New Zealand' [2015].

${ }^{113}$ For example, the Legislative Design Advisory Committee notes ('Legislation Guidelines' (2018) [28.1]) that the courts give privative clause 'a narrow interpretation to preserve their ability to review decisions in at least some circumstances' and 'may not be fully effective even if included'.

${ }^{114}$ National Hydatids Council $v$ Ward HC Tauranga M55/88, 7 June 1989, 1, cited in Pemberton (n 79) 626-27.

${ }^{115} \mathrm{H} v$ Refugee and Protection Officer [2019] NZSC 13, [2019] 1 NZLR 433 [63] (O'Regan J).

116 Zaoui v Attorney-General (No 2) [2005] 1 NZLR 690 (CA) [105] and [181]. See also O’Regan $v$ Lousich: Proprietors of Mawhera v Maori Land Court [1995] 2 NZLR 620 (HC).
} 
was read narrowly in accordance with sections 6 and 27(2) of the NZ Bill of Rights Act 1990.

The Supreme Court's decision in Tannadyce Investments is as an example of greater willingness to respect privative clauses where doing so prevents unnecessary duplicative proceedings, although the Court was split about how privative clauses should be read in such circumstances. ${ }^{117}$ The case was about a privative clause in tax administration legislation which deemed certain decisions correct unless challenged through a statutory dispute process (a merits and legality dispute process involving a specialist tribunal and/or the High Court). Both the majority and minority endorsed Bulk Gas as the controlling authority on the interpretation of the privative clause and accepted the courts should be slow to conclude that the judicial review was ousted. ${ }^{118}$

The majority thought the privative clause legitimately protected the statutory review process, a process itself which provided for the prospect of High Court scrutiny of the legality and merits on the assessment (either directly or through an appeal from the specialist tribunal). Notably, there was 'no need to strain' the interpretation of the privative clause the statutory review procedure had 'a built-in right for the taxpayer to take the matter to the High Court, if that is thought necessary or desirable'. ${ }^{119}$ And, the majority said, judicial review would still be available if it was 'not practically possible' for a taxpayer to engage the statutory dispute process or there was some flaw in the statutory dispute process itself. ${ }^{120}$ In contrast, the minority placed more emphasis on the constitutional importance of 'full supervision by the courts of the conformity of activities of government with the rule of law'. ${ }^{121}$ In their view, a statutory right of appeal should not exclude judicial review. The minority favoured a more contextual assessment in the circumstances of particular cases about whether access to judicial review might be preferred over the statutory dispute process for reasons such as adequacy or effectiveness. In any event, though, the Court unanimously agreed that the taxpayer was precluded from challenging its tax assessment by judicial review in this case. It was not able to bring itself within the residual categories of judicial review under the majority's approach or make a general circumstantial argument that judicial review was preferable under the minority's approach.

This willingness to apply privative clauses if adequate legal accountability is otherwise provided through statutory processes has become pretty common. For example, the Court of Appeal has a number of times ruled that an extensively

\footnotetext{
117 Tannadyce Investments Ltd $v$ Commissioner of Inland Revenue [2011] NZSC 158, [2012] 2 NZLR 153.

118 ibid [56] (Tipping J for the majority); see also [3] (McGrath J for the minority).

$119 \mathrm{ibid}$ [57] (Tipping J for the majority).

120 ibid [58].

121 ibid [4] (McGrath J for the minority).
} 
engineered privative clause protects the Employment Court from judicial review (unusually, a review jurisdiction conferred on the Court of Appeal by statute). ${ }^{122}$ The courts have also followed suit in the immigration sphere, where privative clauses protect tribunal decision-making but are teamed with a right of appeal on questions of law. ${ }^{123}$ And the Supreme Court in McGuire recently enforced a privative clause against a lawyer challenging the loss of his legal aid authorisation; the Court ruled that it was not impracticable for the lawyer to exercise his statutory review rights first and then, if necessary, issue judicial review proceedings later, as the privative clause contemplated and required. ${ }^{124}$ One notable exception is $H v$ Refugee and Protection Officer where the Supreme Court allowed judicial review proceedings despite a privative clause ostensibly protecting an immigration officer's original assessment in refugee legislation. ${ }^{125}$ The Court took a different view from the lower courts on whether a statutory appeal process provided an effective remedy for the unfair cancellation of a refugee claimant's initial interview. ${ }^{126}$ While mindful of the concern about duplicative proceedings in Tannadyce, the Court was not satisfied the statutory appeal to a tribunal was adequate to address the error, especially because the in-person interview and ability to argue the merits of their case twice (once in an initial interview and secondly before the tribunal on review) were critical aspects of fairness and key features of the statutory regime.

Thus, while Anisminic and Bulk Gas are still regarded as rarefied landmarks and frequently cited as expressing the controlling principle, ${ }^{127}$ there has been some dilution of the previous strong hostility towards privative clauses.

\footnotetext{
${ }^{122}$ See eg Parker $v$ Silver Fern Farms [2011] NZCA 564, [2012] 1 NZLR 256; Moodie v Employment Court [2012] NZCA 508, [2012] ERNZ 201; Huang $v$ Li [2013] NZCA 135, (2013) 10 NZELR 514; AFFCO New Zealand Ltd $v$ Employment Court [2017] NZCA 123, [2017] 3 NZLR 603. The privative clause in Employment Relations Act 2000, s 193 excludes review except 'on the ground of lack of jurisdiction' but explicitly defines lack of jurisdiction in historic and narrow terms (no entitlement to enter upon the inquiry in question; outside the classes of decisions or orders authorised to make; bad faith). Notably, the AFFCO case ruled the privative clause did not unjustifiably the right to judicial review in s 27(2) of the NZ Bill of Rights Act 1990.

${ }^{123}$ See eg Phan $v$ Minister of Immigration [2010] NZAR 607 (HC); Ibrahim v Associate Minister of Immigration [2012] NZCA 229 (observation in course of determining security for costs); Liu $v$ Minister of Immigration [2015] NZHC 2048. Compare Kaur v Ministry of Business, Innovation and Employment [2016] NZHC 2595.

${ }^{124}$ McGuire v Secretary for Justice [2018] NZSC 116, [2019] 1 NZLR 335.

${ }^{125} \mathrm{H} v$ Refugee and Protection Officer [2019] NZSC 13, [2019] 1 NZLR 433.

${ }^{126}$ H $v$ Refugee and Protection Officer [2017] NZHC 2160, [2017] NZAR 1518 and H (CA580/2017) $v$ Refugee and Protection Officer [2018] NZCA 188, applying Tannadyce (n 117).

${ }^{127}$ Anisminic itself continues to be heavily cited in the modern era: $H v$ Refugee and Protection Officer [2018] NZCA 188; Ririnui v Landcorp Farming Ltd [2016] NZSC 62, [2016] 1 NZLR 1056; Siemer $v$ Solicitor-General [2013] NZSC 68, [2013] 3 NZLR 441; Huang $v$ Li [2013] NZCA 135, (2013) 10 NZELR 514; Parker v Silver Fern Farms Ltd [2011] NZCA 564, [2012] 1 NZLR 256; Zaoui v Attorney-General (No 2) [2005] 1 NZLR 690 (CA); Commissioner of Inland Revenue $v$ Chesterfields Preschools Ltd [2010] NZCA 400, (2010) 24 NZTC 24,500; R v Strawbridge [2003] 1 NZLR 683 (CA). See also regular citation in the High Court: Carterv Coroner's Court at Wellington [2015] NZHC 1467, [2016] 2 NZLR 133; Bain v Minister of Justice (Discovery) [2013] NZHC 2123, [2014] NZAR 892; and Attorney-General v Palmer (Informer Privilege) [2007] NZAR 112 (HC).
} 
Whether this represents repudiation of the spirit of Anisminic and Bulk Gas or is acknowledgement of the greater sophistication in legislative design and statutory dispute processes is difficult to say. My sense is that it is perhaps the latter, as there seems to be greater attentiveness to the strength (or otherwise) of the accountability and grievance processes provided other than by judicial review. Certainly, it still seems unlikely that the courts would allow privative clauses to protect erroneous decisions from judicial review when judicial review is the only meaningful remedy available. ${ }^{128}$

\section{IMPORTATION AND INDIGENEITY}

The story so far has been about importation and the way in which key developments in the motherland were echoed in New Zealand. But to what extent does the story of indigeneity also feature? It is beyond the scope of this chapter to provide a full assessment of the success or otherwise of the indigeneity project. However, I offer some reflections on the balance between importation and indigeneity and related tensions, especially through the lens of the Quartet and the principles they represent.

\section{A. Derivative Relationship}

The treatment of the Quartet paints a picture about a derivative relationship between the two jurisdictions, especially in the time of the Quartet and the decades that followed. The treatment of this Quartet in New Zealand shows the English influence during this era and beyond. These cases have found their way into New Zealand jurisprudence and have helped shape local administrative law principle, to different degrees. ${ }^{129}$ Anisminic and Ridge $v$ Baldwin were strong catalysts for change in New Zealand for the generalisation of intervention for error of law and process. Padfield fortified and amplified a purposive tradition. And, although not causative, Conway $v$ Rimmer played a role in exposing a greater range of Crown documents to scrutiny. This is consistent with the general assessment at the time. For example, Lord Diplock observed, when sitting on the

\footnotetext{
${ }^{128}$ For a similar turn to a broader constitutionality assessment, rather than linguistic gymnastics or nullity analysis, see M Elliott, 'Through the Looking-Glass? Ouster Clauses, Statutory Interpretation and the British Constitution' in C Hunt, L Neudorf and M Rankin (eds), Legislating Statutory Interpretation: Perspectives from the Common Law World (Toronto, Carswell, 2018).

${ }^{129}$ We could add others. Wellington City Council $v$ Woolworths New Zealand Ltd (No 2) [1996] 2 NZLR 537 echoes Wednesbury. Standing rules were relaxed in Environmental Defence (No 2) (n 36). Local extensions to the supervisory jurisdiction mirror English developments: eg Burt $v$ Governor-General [1992] 3 NZLR 672 (prerogative); Phipps (n 30), and Electoral Commission $v$ Cameron [1997] 2 NZLR 421 (private non- statutory entities). Local rationalisation of the grounds can be pointed to in NZ Fishing Industry Association v Minister of Agriculture \& Fisheries [1988] 1 NZLR 544.
} 
Privy Council deciding a New Zealand case in 1983, the 'principles underlying the exercise of judicial review in New Zealand and in England, at any rate, are the same'. ${ }^{130}$ Looking back, Elias CJ characterised New Zealand's jurisprudence in the latter part of the twentieth century as 'slavish imitation' of English law. ${ }^{131}$ Even today, Francis Cooke QC, son of Lord Cooke, then leading silk and now High Court judge, noted 'we still take our lead from the United Kingdom'. ${ }^{132}$

Thus, we can think of most of the Quartet, especially Ridge $v$ Baldwin and Anisminic, as 'legal transplants', as they are sometimes described. ${ }^{133}$ This type of sharing within the 'common law family' has been, Saunders suggests, 'largely uncontentious'. ${ }^{134}$ But, extending the familial metaphor, the parental relationship animated the attentiveness of the New Zealand courts to English law. As a child of the English common law, ${ }^{135}$ developments in the motherland could not be ignored.

Various institutional and environmental features might go some way to explaining the strength of the derivative relationship. First, institutional form and stare decisis drove attentiveness to the English courts, especially the final appellate courts. Until the establishment of the New Zealand Supreme Court, the common membership of the Privy Council and House of Lords meant judges within the New Zealand judicial system needed to be mindful of the views of English judges when sitting in the House of Lords, for they would also determine any final appeals within the New Zealand system. Strictly speaking, decisions of the House of Lords were not binding, but highly persuasive. Since the establishment of the Supreme Court, the principles of stare decisis have been relaxed. ${ }^{136}$

Secondly, the challenge of scarce resources inevitably conditions the outwardlooking eye. As Hammond J observed in the Lab Tests case, New Zealand's case law suffers from a scarcity problem. Common law judicial review 'scores its

\footnotetext{
${ }^{130}$ Re Erebus Royal Commission; Air New Zealand Ltd v Mahon [1983] NZLR 662, [1984] AC 808 (PC) 668 .

${ }^{131}$ S Elias, 'Address at the Memorial Sitting for the Rt Hon Sir Richardson PCNZM' (2015) 46 Victoria University of Wellington Law Review 15, 16.

${ }^{132} \mathrm{~F}$ Cooke, 'Relief at Last' in Administrative Law (New Zealand Law Society Intensive, August 2008) 31, cited in Lab Tests Auckland Ltd $v$ Auckland District Health Board [2008] NZCA 385, [2009] 1 NZLR 776 [395] per Hammond J.

${ }^{133}$ A Watson, Legal Transplants: an approach to comparative law (Charlottesville, University Press of Virginia, 1974); and A Watson, Comparative law: law, reality and society, 2nd edn (Lake Mary, Florida, Vandeplas Publishing, 2008). See also J Allison, 'Transplantation and Cross Fertilisation in European Public Law' in J Beatson and T Tridimas (eds), New Directions in European Public Law (Oxford, Hart Publishing, 1998).

${ }^{134} \mathrm{C}$ Saunders, 'Apples, Oranges and Comparative Administrative Law' [2006] Acta Juridica 423, 426. The Anglo-Commonwealth jurisdictions have been characterised as having 'a significant degree of doctrinal and institutional similarity, overlying a substratum of considerable cultural difference': 427.

${ }^{135}$ English common law applied the New Zealand colony via the English Laws Act 1858 and subsequent statutes.

${ }^{136}$ D White, 'Originality or Obedience? The Doctrine of Precedent in the 21st Century' (2019) 28 New Zealand Universities Law Review 653.
} 
runs in singles' and, in a small democracy like New Zealand, there is 'only an irregular supply of cases'; thus, 'the run accumulation technique becomes highly problematic'. ${ }^{137}$ Similarly, we might point to the paucity of domestic scholarly works, only recently largely overcome. While New Zealand had a suite of fine administrative law scholars, ${ }^{138}$ it lacked a leading textbook of the kind found in England. Paterson's early and short treatise did not survive and his taxonomy was heavily littered with English authority. ${ }^{139}$ Joseph's constitutional and administrative law text did not arrive until 1993 and then its strength was probably more in relation to matters constitutional. ${ }^{140}$ Taylor's contribution on judicial review came in 1991, but was not next updated until 2010; while grounded in New Zealand jurisprudence, the author also displayed an odd warmth towards Australian administrative law, with lessons from abroad coming as much from New Zealand's nearest neighbour as they did from the motherland. ${ }^{141}$ Smith's recent handbook, modelled on Fordham's, is notable for its (almost) exclusive curation of New Zealand cases. ${ }^{142}$ In short, local jurisprudential inspiration was hard to come by. It is therefore no surprise to see New Zealand cases replete with references to the likes of de Smith, Wade and Craig and so forth. ${ }^{143}$

Thirdly, university schooling conditioned attentiveness to matters English. Key actors within the judicial system - lawyer advocates, judges and the academy itself - were schooled as technicians in English law as much as New Zealand's. Witness Northey's casebook for administrative law at the University of Auckland in the 1970s: again, English case law dominates. ${ }^{144}$ Note Lord Cooke's postgraduate study in Cambridge too.

Fourthly, it seems likely that this derivative relationship was also coloured by broader thoughts about national identity and colonial mentality. New Zealand's 'Englishness' was strong in the early decades being studied. And it was perhaps not until the 1980s that the independence spirit started to gain momentum. ${ }^{145}$

${ }^{137}$ Lab Tests (n 132) [396], building on the metaphor seeded by Professor Burrows. The 'small democracy' terminology was also borrowed, from Willis Airey.

${ }^{138}$ For example, Northey, Paterson, Mullan, Keith and Taggart.

${ }^{139} \mathrm{DE}$ Paterson, An Introduction to Administrative Law in New Zealand (Wellington, Sweet and Maxwell, 1967).

${ }^{140} \mathrm{P}$ Joseph, Constitutional and Administrative Law in New Zealand, 1st edn (Sydney, Law Book Co, 1993; 4th edn (Wellington, Thomson Reuters, 2014).

${ }^{141} \mathrm{On}$ the difficulties of Australia as a comparator jurisdiction, see M Taggart, "'Australian Exceptionalism” in Judicial Review' (2008) 36 Federal Law Review 1.

${ }^{142}$ Smith, Judicial Review Handbook (2016).

${ }^{143}$ Both older and modern cases cite these authors; see eg Buller Hospital (n 8); Ye v Minister of Immigration [2009] 2 NZLR 596 (CA); Hamed $v$ R [2012] 2 NZLR 305 (SC) citing multiple works by Stanley A de Smith and Patel $v$ Chief Executive of Department of Labour [1997] 1 NZLR 102 (HC) and Progressive Enterprises Ltd v North Shore City Council [2006] NZRMA 72 citing Paul Craig at [71].

144 JF Northey (ed), Administrative law casebook (Auckland, University of Auckland, Faculty of Law, 1973).

${ }^{145} \mathrm{~J}$ Belich, Paradise reforged: a history of the New Zealanders from the 1880s to the year 2000 (Auckland, Penguin, 2001). See also H Wilberg and K Gledhill, 'English Administrative Law in 


\section{B. Embellishments and Glosses}

The importation of the Quartet was subject to some indigenous embellishments and glosses. Bulk Gas, while reflecting Anisminic's hostility to privative clauses, employed a more explicit constitutional lens and cared less about linguistic gymnastics when asserting the judicial authority to determine questions of law. The principle in Conway $v$ Rimmer was already embedded in New Zealand jurisprudence and, following convergence, the principle seemed to be applied with considerable vigour, especially as it related to Cabinet papers and documents. Nowadays, the discretionary approach has since been codified. And the transparency culture that has developed in New Zealand (for example, Cabinet papers are nowadays unilaterally disclosed by the Government) means the privilege has almost fallen into abeyance. Padfield, too, reflected a spirit already present in New Zealand jurisprudence; Ireland and Unison Networks are notable for perhaps softening the strength and purity of the Padfield principle, by providing some latitude for decision-makers when multiple purposes or actions are in play.

Yet, in the overall scheme of things, these embellishments and glosses seem relatively minor. The dominant impression is that these strong and well-regarded principles have been deeply embedded, at best with a slight New Zealand accent. ${ }^{146}$

\section{Durability and Ongoing Gravitas}

These transplants imported into New Zealand jurisprudence have proved to be durable and continue to have ongoing gravitas in the modern era. None of the principles has been repudiated; at worst, a couple have been tempered, but probably only to address circumstances different than the original Quartet. As explained, the generalised approach to natural justice continues, perhaps even flourishing further than Ridge $v$ Baldwin. Padfield's purpose principle has been deeply embedded; the only gloss might be the reconciliation of multiple purposes (arguably, this litmus test of not thwarting or undermining the legitimate purpose has its pedigree in Padfield itself). Crown privilege has largely waned in New Zealand, such that Conway $v$ Rimmer is probably now redundant. Anisminic continues to be rarefied in principle, even if its application is somewhat mixed. The potential of Anisminic is nowadays carefully anticipated in legislative and regime design; privative clauses must be constitutionally respectable - such as bespoke and robust accountability processes that still enable recourse to superior courts on errors of law - to have any chance of being honoured.

Aotearoa New Zealand' in S Jhaveri and M Ramsden (eds), Judicial Review of Administrative Action: Origins and Adaptations Across the Common Law World (Cambridge, CUP, 2020) (pointing to New Zealand's 'pragmatism, anti-intellectualism and lack of dogmatism').

${ }^{146}$ For the accent metaphor, see J McLean, 'The unwritten political constitution and its enemies' (2016) 14 International Journal of Constitutional Law 119. 
This seems curious. One might expect that the importation and internalisation of the Quartet might allow the English cases to slide into the shadows. Surely the existence, in every case, of equivalent local cases obviates citation and discussion of the original development? That is not the case, though. The Quartet continue to be cited liberally, especially by appellate courts, either in their own right or in tandem with the local landmark cases. Notably, the courts appear to be more ready to cite the older English cases than contemporaneous ones. ${ }^{147}$ And the Quartet cases continue to be taught to New Zealand students too. A quick survey finds that Ridge $v$ Baldwin, Padfield and Anisminic regularly feature in the current syllabi of administrative law, judicial review or public law courses in New Zealand (Conway $v$ Rimmer features only rarely). ${ }^{148}$

A few factors might inform this durability and ongoing gravitas. First, one possible explanation is the general trajectory of English and New Zealand law from abstract formalism to generalised categories or more circumstantial methods. That is, administrative law doctrine and principle has become more abstracted, such that a singular principle is capable of implicitly providing degrees of nuance not seen before the Quartet. In other words, doctrine itself has become less relevant as it tends to reflect more of a general style or method of analysis. One emblematic example is Ririnui, where the majority showed a strong preference for simply curing an obvious error, rather than determining whether it was properly classified as one of law or fact or resolving the uncertainty about the legitimacy of a mistake of fact ground. ${ }^{149}$ Thus, we can see little judicial interest in (re)shaping common law principles and doctrine; delivering administrative justice on a case-by-case basis was more important. Top-down principle, rather than bottom-up doctrine. ${ }^{150}$ Thus, a focus on principle - rather than application - may obscure the indigenous attitudes of the local courts.

Secondly, the modern-day senior courts in New Zealand may be reluctant curators of law. ${ }^{151}$ While Lord Cooke was at home with the abundance of legal

\footnotetext{
${ }^{147}$ For example, New Health (n 48), cites Padfield [327] for the purpose principle.

${ }^{148}$ Auckland (Ridge v Baldwin, Padfield, Anisminic); AUT (Ridge v Baldwin, Padfield, Anisminic), Canterbury (Ridgev Baldwin, Padfield, Anisminic); Otago (all); Victoria (Padfield, Anisminic).

${ }^{149}$ Ririnui (n 127). Other examples include the surprising refusal of leave in the Lab Tests case (n 132) (court's assessment that the case raised no matters of public importance and turned on its own facts); and Quake Outcasts v Minister for Canterbury Earthquake Recovery [2015] NZSC 27, [2016] 1 NZLR 1 (court avoided the vexed status of the so-called third source of authority).

${ }^{150}$ For this terminology, see S Gageler, 'The Underpinnings of Judicial Review of Administrative Action' (2000) 28 Federal Law Review 303 and RA Posner, 'Legal Reasoning From the Top Down and From the Bottom Up' [1992] University of Chicago Law Review 433. See J Bell, 'Rethinking the Story of Cart $v$ Upper Tribunal and its Implications for Administrative Law' (2019) 31 OJLS 74 for suggestion of a similar turn in English administrative law.

${ }^{151}$ Parsing judicial eras is always difficult. But for this, and other, purposes I have floated the idea of four rough eras: the early Court of Appeal years (running from around when the permanent Court of Appeal was established in 1958); the Cooke era (opening when Cooke J was promoted to the Court of Appeal until his retirement in 1996); a possible but perhaps overlapping Richardson era; and the Supreme Court pioneers (capturing the transition of many members from the Court of Appeal as then de facto local apex court to the new Supreme Court after it was established in 2004).
} 
doctrine, both local and English, and was never shy about reshaping doctrine, the recent and current Supreme Court pioneers display a judicial conservatism that seeks to disclaim any normative curation of law and legal principle in the administrative law domain. Elsewhere I have wondered if the legacy of this modern era is the combination of the appearance of legal triteness, on the one hand, and heavily fact-sensitive assessment, on the other. ${ }^{152}$ The continuing citation of the Quartet plays right into this narrative. The cases are manifestations of long-standing, deeply embedded and uncontroversial principles. Their citation is almost a signal to say, 'there's nothing to see here'. This frees up the court to wade into the circumstances of the cases under appeal, almost as an error-correction court.

Thirdly, we might point to the rise of contextualism. Unstructured normativism and a strong emphasis on the influence of context are thus commonplace in New Zealand. ${ }^{153}$ To the extent that senior courts have reshaped legal principle, the mood is generally in favour of broad and generalised standards which allow for a holistic assessment of the facts. ${ }^{154}$ Some developments emblematic of this contextualism include a monolithic but fact-sensitive approach to reasonableness, rejection of doctrinal deference, and occasional deployment of the innominate ground (which mandates intervention whenever judicial intervention is justified).

\section{Overall Trajectory}

If we reflect on the Quartet less in terms of their individual contributions and more as signposts of a jurisprudential trajectory or fashions in judicial philosophy, then the importation/indigeneity picture changes a little bit.

The traditional account of English judicial review tends to start with the 'classic model' - 'highly individualistic and conspicuously marked by judicial restraint'. ${ }^{155}$ The Quartet signals the reawakening and the emergence of more

See DR Knight, 'Courts and the Executive: A Story (Some Stories?) About Judicial Review in New Zealand' (paper presented to Institute of Judicial Studies 'Challenge and Change' symposium (Wellington, August 2017)). These comments relate to the latter era.

${ }^{152}$ Knight, 'Courts and the Executive' (2017).

${ }^{153}$ DR Knight, 'Contextual review: the instinctive impulse and unstructured normativism in judicial review' (2020) 40 Legal Studies 1; DR Knight, 'Modulating the Depth of Scrutiny in Judicial Review: Scope, Grounds, Intensity, Context' [2016] New Zealand Law Review 63.

${ }^{154}$ Wilberg and Gledhill, 'English Administrative Law' (2020), speak of an 'almost complete eschewal of reasoning from general principles or reliance on authority in administrative law, deciding the vast majority of case as matters simply of statutory interpretation'.

${ }^{155} \mathrm{C}$ Harlow, 'A Special Relationship? American Influences on Judicial Review in England' in I Loveland (ed), A Special Relationship? American Influences on Public Law in the UK (Oxford, Clarendon Press, 1995) 83. See also M Taggart, 'Reinventing Administrative Law' in N Bamforth and P Leyland, Public Law in a multi-layered constitution (Hart Publishing, Portland, 2003) 312 and J Steyn, The Constitutionalisation of Public Law (London, Constitution Unit, 1999) 2-6. 
active judicial supervision. ${ }^{156}$ Then followed the systemisation efforts of Lord Diplock, culminating in the CCSU re-expression of the tripartite grounds. ${ }^{157}$ The so-called rights-revolution then followed, along with Europeanisation. ${ }^{158}$

It is fair to say that the general long-term trajectory is common, especially in the early creation phases, as has been shown with the Quartet. The transition from neglect to reawakening to rationalisation is a shared history: sometimes parallel, sometimes parasitic. We might, though, doubt whether the administrative law rights revolution was as strongly felt in New Zealand. The adoption of a statutory Bill of Rights, some time before the British equivalent, immunised common law judicial review from pressures to recraft doctrine and method to more fully embrace rights. That said, the principle of legality is well embedded in local jurisprudence, without the same fanfare as seen in England. ${ }^{159}$ While the Bill of Rights discipline continues to be vigorous, it does not appear to have had the same deep impact on administrative law; in particular, although it is widely assumed that the Bill of Rights mandates proportionality review, there is little evidence of this actually being applied in practice in administrative law cases. ${ }^{160}$ And, of course, the New Zealand courts have not had to grapple with the ongoing reach of Continental Europe and its influence - both direct and indirect - on English law.

An alternative way - and one I prefer - to think about the overall trajectory is to think in terms of the meta-structure of judicial method. ${ }^{161}$ We can track the trajectory with a different lens, by reference to different methods used to draw the balance between primary issues (the propriety of administrative action in a particular case) and secondary issues (judicial legitimacy in terms of relative expertise and competence to adjudicate on different questions). ${ }^{162}$

\footnotetext{
${ }^{156}$ Harlow, 'A Special Relationship?' (1995) 84; M Taggart, 'Proportionality, deference, Wednesbury' [2008] New Zealand Law Review 423, 429. See R Austin, 'Administrative Law's Reaction to the Changing Concepts of Public Service' in P Leyland and T Woods (eds), Administrative Law Facing the Future (London, Blackstone, 1997) 30.

${ }^{157}$ Council of Civil Service Unions v Minister for the Civil Service [1985] AC 374. Such work was probably more symbolic than instrumental. As Harlow and Rawlings note, while CCSU is ' $[\mathrm{u}]$ sually cited as the basis of the modern doctrine of judicial review', the grounds 'still conform[ed] largely to the classical grounds as they had evolved over the centuries'; C Harlow and R Rawlings, Law and Administration (Cambridge, Cambridge University Press, 2012) 107. See also M Fordham, 'Surveying the Grounds: Key Themes in Judicial Intervention' in Leyland and Woods, Facing the Future (1997) 199.

${ }^{158}$ For a recent alternative account, see JNE Varuhas, Damages and Human Rights (Oxford, Hart Publishing, 2016).

${ }^{159}$ See eg Cropp v Judicial Committee [2008] 3 NZLR 774; R v Pora [2001] 2 NZLR 37; Drew $v$ Attorney-General [2002] 1 NZLR 58; Canterbury Regional Council v Independent Fisheries Ltd [2013] 2 NZLR 57; Attorney-General v Spencer [2015] 3 NZLR 449.

${ }^{160} \mathrm{C}$ Geiringer, 'Sources of Resistance to Proportionality Review of Administrative Power Under the New Zealand Bill of Rights Act' (2013) 11 New Zealand Journal of Public and International Law 123.

${ }^{161}$ Knight, Vigilance and Restraint (2018).

162 ibid.
} 
Four main styles, generalised to a degree of abstraction, are evident over the last half century or so:

(a) scope of review, where the effective depth of scrutiny is determined indirectly based on categorical distinctions and formalistic reasoning; ${ }^{163}$

(b) grounds of review, where judicial intervention is conditioned by a framework of a few generalised grounds of review, expressed with a degree of abstraction; ${ }^{164}$

(c) intensity of review, where the depth of scrutiny is determined explicitly, by reference to a range of constitutional and institutional factors;

(d) contextual review, where doctrine is largely abandoned, whether in the form of categories, grounds or factors, in favour of normative reasoning and judgement. ${ }^{165}$

The Quartet fell in the middle of the scope of review period and before the systemisation work of Lord Diplock and Lord Cooke ushered in the grounds of review approach. New Zealand generally tracked the English method during this period and both jurisdictions still employ a grounds of review framework as the general starting point.

Within a 'grounds of review' approach, we might reflect on whether the grounds themselves display any cues of indigeneity. There is symmetry between the traditional grounds of review (illegality, procedural impropriety and irrationality; in accordance with law, fairly and reasonably). Parallel efforts to reshape these grounds and to enlarge the suite of grounds is largely common to both countries, albeit with less cut-through in New Zealand. ${ }^{166}$

\footnotetext{
163 The courts' ability to intervene was conditioned according to rigid categories of analysis: jurisdictional-non-jurisdictional, law-fact-policy, process-substance, judicial-administrative-legislative; and was very technical and formalistic, as well as being rigid and circumspect; hence, the style was usually (but not always) teamed with judicial restraint. This echoes Carol Harlow's 'classic model'. On formalism see D Dyzenhaus, 'Constituting the Rule of Law' (2002) 27 Queen's Law Journal 445,450 .

${ }^{164}$ The expression of these 'court-recognised rules of good administration' in systemic and simplified form, often in tripartite form (illegality, procedural impropriety and irrationality; in accordance with law, fairly and reasonably), with the grounds themselves expressing different emphases on vigilance and restraint.

${ }^{165}$ In its strong form, doctrine is replaced with the judicial instinct and a discretionary judgment: 'whether something has gone wrong that justifies the intervention of the court?' (eg $R v$ Panel on Take-overs and Mergers, exp Guinness plc [1989] 2 WLR 863); and, in its weaker form, it captures doctrinal frameworks which are so open-textured that their essential feature is an overall evaluative judgement, such as substantive fairness.

${ }^{166}$ Knight (n 151). Substantive legitimate expectation: an accepted alternative ground but successful claims are rare, usually failing on the preliminary question of whether a reasonable expectation exists. Free-standing mistake of fact ground of review floated by Lord Cooke in the 1980s (Dagayanasi, $\mathrm{n}$ 7) but is still not definitely adopted by appellate courts, even though occasionally relied on in High Court decisions. Proportionality is not recognised as a generally available ground but provides a basis for intervention in limited situations: arguably human rights adjudication (but less so in practice than received wisdom suggests); disproportionate penalties; and, perhaps, challenges to local authority bylaws. Inconsistency of the even-handed kind has only partly been recognised, as a touchstone of unreasonableness. The potential of a ground of substantive fairness
} 
And there is a sense that there is greater enthusiasm for, and increasing examples of, contextual review. ${ }^{167}$ Perhaps that is the richest site for the development of an indigenous judicial style?

\section{E. Bespoke Procedural Infrastructure}

I wonder if the inspiration for Lord Cooke's indigeneity remarks stems largely from the reforming work of the Public and Administrative Law Reform Committee's work to simplify the procedure for judicial review. ${ }^{168}$ It is here that the adoption - or, rather, importation from Canada - of the Judicature Amendment Act 1972 as the governing procedure statute for most judicial review applications plotted a different course for New Zealand from the motherland. ${ }^{169}$

Well-known concerns that the prerogative writs and orders were cumbersome for applicants led to procedural reform of the writs in the 1970s and the introduction of the simplified judicial review procedure. ${ }^{170}$ The critical provision allows the High Court to grant any relief available under the prerogative writs or other extraordinary remedies 'in relation to the exercise, refusal to exercise, or proposed or purported exercise by any person of a statutory power' a term defined extensively. ${ }^{171}$ In general terms, this provision provides a more sympathetic environment in which to engage judicial review. And it avoids the procedural complexities associated with the prerogative writs. Introduced as a 'process' statute, the Judicature Amendment Act 1972 only addressed procedural and remedial matters; it did not purport to codify or modify the common law grounds of judicial review. ${ }^{172}$

One gets the impression that Lord Cooke saw this vehicle as a key means of charting a different course and avoiding the doctrinal morass that had plagued English administrative law, especially in the decades before its enactment.

was promoted in the late 1980s and early 1990s, but has since been overtaken by the variegated forms of unreasonableness. The so-called innominate ground (as seeded by the English Court of Appeal in Guinness, n 165) has been deployed in New Zealand on a few occasions but recent attempts to revive it have been soundly knocked back.

${ }^{167}$ Knight (n 79) 201-04.

${ }^{168}$ Sir Robin Cooke, 'Public and Administrative Law Reform Committee: The Early Years' (1989) 13 New Zealand Universities Law Review 150.

${ }^{169}$ Now re-enacted as the Judicial Review Procedure Act 2016.

${ }^{170}$ New Zealand Law Commission, 'Mandatory Orders Against the Crown and Tidying Judicial Review' (Issues Paper 10, 2001) [49]; New Zealand Law Commission, 'Review of Prerogative Writs' (Issues Paper 9, 2008) [1.10]. In particular, the prerogative writs regime required applicants to correctly specify and rely on a particular writ and provided no sympathy if it was subsequently determined another writ was more apt.

${ }^{171}$ Judicial Amendment Act 1972, s 4 (emphasis added). The one exception is removal from office, which, while an extraordinary remedy under Part 30, is not referred to in s 4 of the Act.

${ }^{172}$ Law Commission, 'Review of the Judicature Act 1908: Towards a New Courts Act' (Report 126, 2012) [2.1] and Mercury Energy Ltdv Electricity Corporation of New Zealand [1994] 2 NZLR 385 (PC). 
As it relates to procedure, that has generally proved to be the case. ${ }^{173}$ But, as the Judicature Amendment Act neither sought to codify or freeze the then existing substantive principles, nor attempted to modify them, the reform was agnostic to the underlying principles of the common law. At best, the reform catalysed a concern for simplicity, something that was a distinctive feature of Lord Cooke's own contribution. Thus, a degree of indigeneity but with little impact on the importation of substantive principles from England.

\section{CONCLUSION}

Importation and indigeneity are two stories that can be told about New Zealand administrative law. The Quartet provides useful chapters for these stories. The faithful application of these English cases in New Zealand speaks to a strong tradition of importation. Ridge $v$ Baldwin, Padfield and Anisminic made significant impressions on judicial review doctrine in New Zealand, and Conway $v$ Rimmer brought conformity of principle between English and New Zealand law, even if English law was second to move. The indigeneity story is more muted and has failed to realise the full potential presaged by Lord Cooke in the mid-1980s. Local developments hint at indigeneity of administrative law principle. But the reliance on English law - including the Quartet - continues to limit and cloud the development of a distinctive common law of judicial review, even after the establishment of the Supreme Court in New Zealand. Thus, importation and indigeneity continue to be central stories of the historical and contemporary character of judicial review in New Zealand - and are competing stories which suggest an unresolved tension in the legal system's creation story.

${ }^{173}$ See DR Knight, 'Privately Public' (2013) 24 Public Law Review 108. 